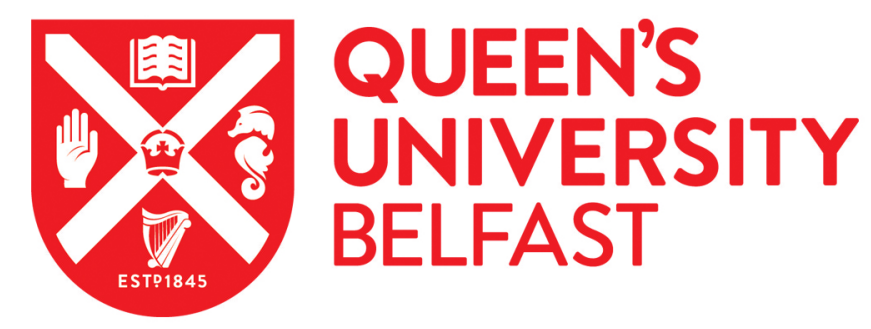

\title{
Whey Protein Complexes with Green Tea Polyphenols: Antimicrobial, Osteoblast-Stimulatory, and Antioxidant Activities
}

Carson, M., Keppler, J. K., Brackman, G., Dawood, D., Vandrovcova, M., Fawzy El-Sayed, K., Coenye, T., Schwarz, K., Clarke, S., Skirtach, A. G., \& Douglas, T. EL. (2019). Whey Protein Complexes with Green Tea Polyphenols: Antimicrobial, Osteoblast-Stimulatory, and Antioxidant Activities. Cells, tissues, organs. https://doi.org/10.1159/000494732

Published in:

Cells, tissues, organs

Document Version:

Peer reviewed version

Queen's University Belfast - Research Portal:

Link to publication record in Queen's University Belfast Research Portal

Publisher rights

(๖) 2019 S. Karger AG, Basel. This work is made available online in accordance with the publisher's policies. Please refer to any applicable terms of use of the publisher.

\section{General rights}

Copyright for the publications made accessible via the Queen's University Belfast Research Portal is retained by the author(s) and / or other copyright owners and it is a condition of accessing these publications that users recognise and abide by the legal requirements associated with these rights.

Take down policy

The Research Portal is Queen's institutional repository that provides access to Queen's research output. Every effort has been made to ensure that content in the Research Portal does not infringe any person's rights, or applicable UK laws. If you discover content in the Research Portal that you believe breaches copyright or violates any law, please contact openaccess@qub.ac.uk. 
Whey protein complexes with green tea polyphenols: antimicrobial, osteoblast-stimulatory and

antioxidant activities

Matthew Carson ${ }^{1}$, Julia K. Keppler ${ }^{2}$, Gilles Brackman ${ }^{3}$, Daniel Dawood ${ }^{4}$, Marta Vandrovcova ${ }^{5}$, Karim Fawzy El-Sayed $^{4,6}$, Tom Coenye ${ }^{3}$, Karin Schwarz ${ }^{2}$, Susan A. Clarke ${ }^{1}$, Andre G. Skirtach ${ }^{7,8}$, Timothy E.L. Douglas ${ }^{7,9,10^{*}}$

${ }^{1}$ School of Nursing and Midwifery, Queen's University Belfast, Belfast, United Kingdom, ${ }^{2}$ Christian-AlbrechtsUniversität zu Kiel, Department of Food Technology, Institute of Human Nutrition and Food Science, Kiel,

Germany, ${ }^{3}$ Laboratory of Pharmaceutical Microbiology, Ghent University, Ghent, Belgium, ${ }^{4}$ Clinic for Conservative Dentistry and Periodontology, School for Dental Medicine, Christian-Albrechts-University Kiel, Kiel, Germany, ${ }^{5}$ Department of Biomaterials and Tissue Engineering, Institute of Physiology, the Czech Academy of Sciences, Prague, Czech Republic, ${ }^{6}$ Oral Medicine and Periodontology Department, Faculty of Oral and Dental Medicine, Cairo University, Egypt, ${ }^{7}$ Department of Molecular Biotechology, Faculty of Bioscience Engineering, Ghent University, Belgium, ${ }^{8}$ Centre for Nano- and Biophotonics, Ghent University, Belgium, ${ }^{9}$ Engineering Department, Lancaster University, United Kingdom, ${ }^{10}$ Materials Science Institute (MSI), Lancaster University, United Kingdom.

Short title: Combined biological effects of beta-lactoglobulin with green tea polyphenols

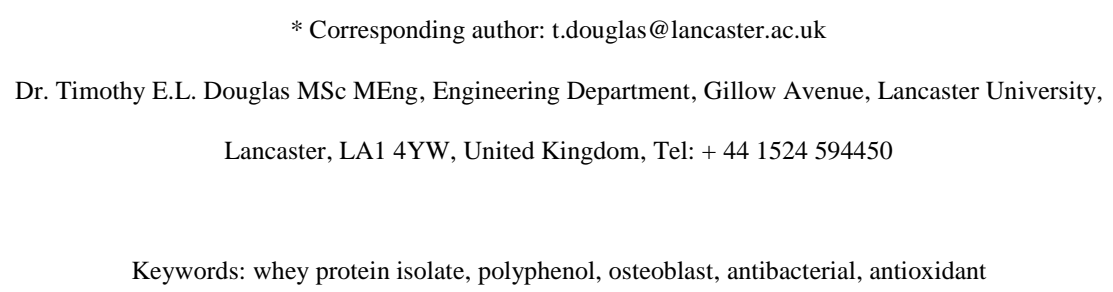




\section{Abstract}

30 Polyphenols are known for their antimicrobial activity, whilst both polyphenols and the globular protein beta31 lactoglobulin (bLG) are suggested to have antioxidant properties and to promote cell proliferation. These are 32 potentially useful properties to have as part of a tissue engineered construct, though it is unknown if they are 33 retained when both compounds are used in combination. In this study, a range of different microbes and an 34 osteoblast-like cell line (hFOB) were used to assess the combined effect of; (1) a green tea extract (GTE), rich in 35 the polyphenol epigallocatechin gallate (EGCG), and (2) a whey protein isolate (WPI), rich in bLG. It was 36 shown that approximately $20-48 \%$ of the EGCG in GTE reacted with WPI. GTE inhibited the growth of gram37 positive bacteria, an effect which was potentiated by the addition of WPI. GTE alone also significantly inhibited 38 the growth of hFOB cells after 1, 4 and 7 days of culture. Alternatively, WPI significantly promoted hFOB cell 39 growth in the absence of GTE and attenuated the effect of GTE at low concentrations (64 $\mu \mathrm{g} / \mathrm{ml})$, after 4 and 7 40 days. Low concentrations of WPI $(50 \mu \mathrm{g} / \mathrm{ml})$ also promoted expression of the early osteogenic marker alkaline 41 phosphatase (ALP) by hFOB cells, whereas GTE inhibited alkaline phosphatase ALP activity. Therefore, the 42 antioxidant effects of GTE can be boosted by WPI, but it is not suitable to be used as part of a tissue-engineered 43 construct due to its cytotoxic effects which negate any positive effect of WPI on cell proliferation. 


\section{List of Abreviations}

ALP $=$ alkaline phosphatase

ANOVA = one-way analysis of variance

ATCC $=$ the American Type Culture Collection

bLG $=$ beta-lactoglobulin

$\mathrm{BOF}=$ Bijzonder Onderzoeksfonds (Special Research Fund)

$\mathrm{CFU}=$ colony forming units

$\mathrm{DAD}=$ diode array detector

$\mathrm{ddH}_{2} \mathrm{O}=$ sterile ultra-pure water

DFG $=$ Deutsche Forschungsgemeinschaft (German Research Foundation)

DMEM = Dulbecco's modified Eagle medium

DNA $=$ deoxyribonucleic acid

DPPH = 2,2-diphenyl-1-picrylhydrazyl

$\mathrm{EC}=$ epicatechin

$\mathrm{ECG}=$ epicatechingallate

$\mathrm{EGC}=$ epigallocatechine

EGCG = epigallocatechin gallate

EUCAST $=$ The European Committee on Antimicrobial Susceptibility Testing

FRAP $=$ ferric reducing ability of plasma

FWO $=$ Fonds voor Wetenschappelijk Onderzoek - Vlaanderen (Research Foundation- Flanders)

$\mathrm{GTE}=$ green tea extract

hFOB = human foetal osteoblast

HPLC $=$ high performance liquid chromatography

$\mathrm{MgCl}_{2}=$ magnesium chloride

MH broth = Mueller-Hinton broth

$\mathrm{MIC}=$ minimal inhibitory concentration

MRSA = methicillin-resistant Staphylococcus aureus

$\mathrm{NaCl}=$ sodium chlorid

$\mathrm{NaOH}=$ sodium hydroxide

PBS $=$ phosphate buffered saline

ROS $=$ reactive oxygen species

RPMI medium = Roswell Park Memorial Institute medium

S.D. = standard deviation

TEAC $=$ Trolox equivalent antioxidant capacity

TFA $=$ trifluoracetic acid

$\mathrm{WPI}=$ whey protein isolate 


\section{Introduction}

Antibacterial properties are highly desirable characteristics for bone regeneration materials, especially in oral and maxillofacial surgery due to the high microbial load of the oral cavity (George et al. 1994; Chen et al. 2010; Gosau et al. 2016). Due to the increasing occurrence of antibiotic-resistant bacteria, such as methicillin-resistant Staphylococcus aureus (MRSA) (Klein et al. 2016; Kavanagh et al. 2017), there is a pressing need to find alternative low cost antibacterial agents, to which there is little resistance.

Green tea extract (GTE) is known to be rich in polyphenols, which in turn possess antibacterial activity (Zhao et al. 2001; Gharib et al. 2013) (for a review see (Steinmann et al. 2013)). One major polyphenol of GTE is epigallocatechin gallate (EGCG), which shows antibacterial activity against MRSA (Gharib et al. 2013) and is alleged to stimulate the growth and differentiation of bone-forming cells (Vali et al. 2007; Jin et al. 2014). To improve stability of EGCG, it is commonly combined with carrier proteins, such as the globular protein betalactoglobulin (bLG) (Keppler et al. 2015). bLG is a major component of whey protein isolate (WPI), derived from milk. It consists of 162 amino acid residues, has a molecular weight of approximately $18.4 \mathrm{kDa}$ and is known to be able to bind hydrophobic molecules (Kontopidis et al. 2004). Besides its application as a carrier protein, bLG has been reported to improve the proliferation of various mammalian cells (Moulti-Mati et al. 1991; Mahmud et al. 2004; Gillespie et al. 2015). It is therefore hypothesised that bLG would also positively influence osteoblast growth, which would be desirable for bone regeneration applications.

Oxidative stress plays an important role in the immune response and has been identified as a pathological inducer in almost all organs (Wauquier et al. 2009). Despite its role in cell signaling, an increased level of oxidative stress can cause bone loss, leading to conditions such as osteoporosis, bone tumor development and inappropriate ingrowth of bone implants. Furthermore, increased levels of reactive oxygen species (ROS) have a supportive effect on osteoclasts, the cells responsible for bone resorption (Garrett et al. 1990; Bai et al. 2005). Thus, antioxidant activity of compounds used during bone substitution could conceivably improve the stability of an implant. EGCG and bLG both have antioxidant activity, which make them excellent candidates as loading agents for bone tissue regeneration (Tong et al. 2000; Tobi et al. 2002; Mann et al. 2015).

Although there is some data available on the micro and cell biological effects of GTE, WPI and their components, the effects of GTE and WPI in combination remain unexplored. It was therefore hypothesized that WPI would influence GTE's antimicrobial and antioxidant activity, as well as its impact on osteoblast growth/differentiation. In the present study, chemical interaction of GTE and WPI was analyzed by centrifugation, ultrafiltration and subsequent high performance liquid chromatography (HPLC) analyses. Antimicrobial activity was tested against a range of bacteria (both Gram-positive and Gram-negative) and fungi, whilst effects on osteoblast proliferation and differentiation were tested using an osteoblastic cell line. Finally, antioxidant properties were investigated using the DPPH (2,2-diphenyl-1-picrylhydrazyl) method. GTE has substantial antimicrobial and antioxidant capability and binds to WPI, which displayed positive effects on osteoblast activity.

\section{Materials and Methods}

Materials 
Unless stated otherwise, all reagents were obtained from Sigma-Aldrich. WPI (BiPRO, Davisco Foods International, Inc., Eden Prairie, US) with $97.7 \%$ protein and $75 \%$ bLG in dry matter (according to specification) was used as previously described (Serfert et al. 2014; Keppler et al. 2017). GTE, > 95\% (obtained from green tea leaves, catechins content $>75 \%, \mathrm{EGCG}>65 \%$; according to specification) was purchased from Oskar Tropitzsch e. K. (Marktredwitz, Germany).

\section{Material analysis}

Analysis of WPI

The composition of the WPI was determined using a method described previously (Clawin-Radecker et al. 2000; Keppler et al. 2014). Briefly, a HPLC HP 1100 system (Agilent Technology, Germany) equipped with a PLRP-S $300 \AA 8 \mu \mathrm{m}, 150 \times 4.6 \mathrm{~mm}$ column (Polymer Laboratories, Varian, Inc.) and a diode array detector (DAD) at $205 \mathrm{~nm}$ wavelengths was used. Eluent A was $0.1 \%$ trifluoracetic acid (TFA) in wa ter and eluent B was $0.1 \%$ TFA in acetonitrile. The following gradient was used: $0 \mathrm{~min}, 35 \% \mathrm{~B} ; 1 \mathrm{~min}, 35 \% \mathrm{~B} ; 8 \mathrm{~min}, 38 \% \mathrm{~B} ; 16$ $\min , 42 \%$ B; $22 \min , 46 \%$ B; $22.5 \min , 100 \%$ B; $23 \min , 100 \%$ B and $23.5-30 \mathrm{~min}, 35 \%$ B. Flow rate was 1 $\mathrm{ml} / \mathrm{min}$, the injection volume was $20 \mathrm{ml}$ and the column temperature was set to $40{ }^{\circ} \mathrm{C}$. Standards of bovine serum albumin, alpha-lactalbumin and beta-lactoglobulin were run for identification.

\section{Analysis of GTE}

GTE was analysed by HPLC (Agilent 1100, with a DAD at $280 \mathrm{~nm}$ wavelength) using a C18-Nucleodur Sphinx 125/4 reversed phase column, $5 \mu \mathrm{m}$ (Macherey-Nagel GmbH \& Co. KG, Düren, Germany). Eluent A consisted of water with $0.1 \%$ formic acid, whilst eluent B was acetonitrile with $0.1 \%$ formic acid. The following gradient was used: 0-1 $\min , 5 \% \mathrm{~B} ; 1-10 \min , 95 \% \mathrm{~B} ; 10-10.5 \min , 95 \% \mathrm{~B} ; 10.5-11 \min , 5 \% \mathrm{~B}$ and $11-12 \min , 5 \%$ B. Standards of the GTE components (EGCG, epigallocatechine (EGC), epicatechingallate (ECG) and epicatechin (EC)) were run to identify the respective signals in the GTE. Percentage composition of the components was assessed semiquantitatively, by comparing individual peak areas to the sum of all peak areas.

\section{Binding studies}

For binding analysis, approximately $4 \mathrm{mg} / \mathrm{ml}$ WPI in water were weighed together with GTE in a concentration ratio of 1:0.08 $\mathrm{g}(\mathrm{w} / \mathrm{w}), 1: 0.16 \mathrm{~g}(\mathrm{w} / \mathrm{w}), 1: 0.32 \mathrm{~g}(\mathrm{w} / \mathrm{w})$ and 1:0.64 $\mathrm{g}(\mathrm{w} / \mathrm{w})$. Subsequently, samples were dissolved in demineralized water for $30 \mathrm{~min}$ at room temperature with vigorous stirring. For control, solutions of GTE without WPI were prepared at a similar concentration. Vivaspin 2 centrifugal filtration devices (Hydrosart $\circledast$ regenerated cellulose membrane, $10 \mathrm{kDa}$ ), from Sartorius AG (Göttigen, Germany), were rinsed with $2 \mathrm{ml}$ demineralized water. Following this, $1 \mathrm{ml}$ of the respective sample solution (i.e. GTE with and without WPI) was centrifuged, using $4000 * \mathrm{~g}$ for $2 \mathrm{~min}$ at $20^{\circ} \mathrm{C}$ - in a swinging-bucket rotor centrifuge. The filtrate and remaining retentate were discarded and replaced again by $1 \mathrm{ml}$ of sample solution. After centrifugation, the filtrate was analysed via HPLC, using the aforementioned method for GTE analysis. As controls, uncentrifuged GTE samples were also analysed, to determine the amount of GTE lost in the membrane during filtration.

\section{Antioxidant method (DPPH test)}

The radical scavenging activity of the different WPI/GTE complexes was analysed using a modification of the DPPH test described by Harbaum et al. (Harbaum et al. 2008). The DPPH assay was carried out by mixing $1 \mathrm{~mL}$ 
of $0.3 \mathrm{mmol} / \mathrm{L}$ 2,2-diphenyl-1-picrylhydrazyl (DPPH radical) in ethanol with $1.95 \mathrm{~mL}$ of $25 \%$ aqueous ethanol, containing $0.1 \mathrm{M}$ phosphate buffered saline (PBS) buffer. This gave a final $50 \%$ ethanolic solution. An initial reading was carried out at $516 \mathrm{~nm}$ (initial absorbance approximately 1.3). Subsequently, a $50 \mu \mathrm{L}$ sample (also dissolved in ethanol) was added, and the absorbance was measured after 10 minutes of reaction time. The antioxidative capacity was given as \% inhibition: \%inh $=([\mathrm{A} 0-\mathrm{A} 1] / \mathrm{A} 0) * 100$, where $\mathrm{A} 0$ is the initial absorbance of the standard and $\mathrm{A} 1$ is the absorbance of the sample.

\section{Antibacterial studies}

Staphylococcus aureus ATCC 700699, ET199 and LMG10147, Staphylococcus epidermidis ET086 and P. aeruginosa ATCC9027 were cultured aerobically in Mueller-Hinton broth (MH; Oxoid, Basingstoke, England), at $37^{\circ} \mathrm{C}$. Propionibacterium acnes LMG 16711 was cultured anaerobically in Reinforced clostridial medium (RCM; Oxoid), at $37^{\circ} \mathrm{C}$. Candida albicans ATCC MYA-2876 was cultured aerobically in RPMI 1640 medium (Sigma-Aldrich, Diegem, Belgium), at $37^{\circ} \mathrm{C}$.

Determination of the Minimal Inhibitory Concentration (MIC): MIC of GTE alone or in the presence of WPI (50 or $800 \mu \mathrm{g} / \mathrm{ml}$ ) was determined according to the EUCAST broth microdilution protocol, using flat-bottom 96-well microtiter plates (TPP, Trasadingen, Switzerland). The inoculum was standardized to approximately $5 \times$ $10^{5}$ colony forming units $(\mathrm{CFU}) / \mathrm{ml}$. The concentration of GTE tested ranged from $0.5-1024 \mu \mathrm{g} / \mathrm{ml}$. The plates were incubated at $37^{\circ} \mathrm{C}$ for $24 \mathrm{~h}$, and the optical density at $590 \mathrm{~nm}$ was determined using a multilabel microtiter plate reader (Envision; Perkin-Elmer LAS, Waltham, MA). MIC was recorded as the lowest concentration of GTE, alone or in combination with WPI, which displayed a similar optical density as that observed in inoculated and blank wells.

\section{Cytocompatibility testing using fibroblasts}

Human fibroblasts were isolated from the gingiva of seven patients (4 female, aged 21, 25, 20 and 20 years and 3 male, aged 36, 21 and 21 years) cultured in cell culture medium (Eagle's minimum essential Medium Alpha modification (Sigma-Aldrich GmbH, Hamburg, Germany), antibiotics (100 U x mL-1 Penicillin, $100 \mu \mathrm{g} \mathrm{x} \mathrm{mL-1}$ Streptomycin, Biochrom, Berlin, Germany), $1 \%$ Amphotericin (Biochrom), $15 \%$ fetal bovine serum (FBS) (HyClone, Logan, Utah, USA) and $400 \mathrm{mmol} \times \mathrm{ml}-1$ L-Glutamine) for 7 days, then medium was exchanged three times per week Ethical approval (number D444/10) was obtained from University Hospital SchleswigHolstein, Campus Kiel, Germany. Fibroblasts in the third passage were pooled and $5 \times 10^{3}$ were seeded in 96 well plates, i.e. $1.56 \times 10^{4}$ cells $/ \mathrm{cm}^{2}$. Cytocompatibility was assessed by incubating cells with medium containing 0,50 or $800 \mu \mathrm{g} / \mathrm{ml}$ WPI and $0,64,128,256,512,1024,2048$ or $4096 \mu \mathrm{g} / \mathrm{ml}$ GTE. Morphology was assessed by light microscopy after 7 days of culture. Medium was changed 3 times during this period.

\section{Cytocompatibility testing using hFOB osteoblast-like cells}

An immortalized human foetal osteoblast (hFOB) cell line (hFOB 1.19; LGC Standards, USA) was used in this study, cultured in Dulbecco's modified Eagle medium (DMEM)/F12 (1:1) medium, supplemented with 10\% FBS, $1 \%$ L-glutamine and $0.6 \%$ geneticin (all Gibco, Life Technologies, UK). Treatments were prepared at concentrations detailed in section 2.6 , filter sterilised $(0.22 \mu \mathrm{m})$ before use and protected from light. Cells were 
seeded at $1 \times 10^{5}$ cells/ $/ \mathrm{cm}^{2}$ on 96 -well sterile culture plates and given a 24 hour settling period before treatment. For all experimental conditions $\mathrm{n}=4$.

\section{hFOB proliferation}

Proliferation was measured by crystal violet staining at 1,4 and 7 days. After removing culture medium by aspiration, cells were fixed with $100 \mu \mathrm{l}$ of $4 \%$ paraformaldehyde solution for $1 \mathrm{hr}$ at room temperature, washed twice with $\mathrm{ddH}_{2} \mathrm{O}$ and left to air dry. Cell monolayers were then stained for 30 minutes at room temperature with $100 \mu \mathrm{l}$ of crystal violet solution per well $\left(0.1 \%\right.$ concentration), washed twice again in $\mathrm{ddH}_{2} \mathrm{O}$ and air dried. Finally, the dye was extracted from monolayers by the addition of $100 \mu 1$ of $1 \mathrm{M}$ acidified methanol. Absorbance was read at $585 \mathrm{~nm}$ using a Tecan GENios microplate reader, and blanked using acidified methanol.

\section{hFOB differentiation}

Alkaline phosphatase (ALP), an enzyme produced by maturing osteoblasts, was used as an indicator of cell differentiation. Briefly, cells were grown in complete medium supplemented with $10 \mu \mathrm{M} \beta$-glycerophosphate and $50 \mu \mathrm{M}$ ascorbate-2-phosphate for 7, 14 or 21 days, before being washed with an alkaline buffer solution (5M $\mathrm{NaCl}, 1 \mathrm{M}$ Tris-Cl pH 9.5, $1 \mathrm{M} \mathrm{MgCl}_{2}$ ). Cells were lysed by addition of $250 \mu \mathrm{l}$ of buffer - containing $0.2 \%$ Triton $\mathrm{X}-100$ - and left to gently mix for 20 minutes on ice, before being stored at $-80^{\circ} \mathrm{C}$. Upon testing, $50 \mu 1$ from each well was added to a test plate in duplicate. $200 \mu 1$ of conditioned medium, consisting of alkaline buffer solution (Sigma) and p-nitrophenyl phosphate substrate was added to each well. Each test plate was then covered in foil and incubated for $30 \mathrm{~min}$ at $37^{\circ} \mathrm{C}$, allowing the coupled enzymatic reaction to proceed. The reaction was stopped by the addition of $50 \mu \mathrm{l}$ of stop solution $(3 \mathrm{M} \mathrm{NaOH})$ and absorbance was read at $450 \mathrm{~nm}$. Finally, ALP readings were normalised to DNA concentration, determined via PicoGreen assay (in a method according to the manufacturer's protocol), to account for the effect of variances in cell proliferation.

\section{Statistical analysis}

Each result set is presented as the mean \pm S.D. (Standard Deviation) and has been tested for normality, after undergoing a logarithmic transformation. Differences between treatments were analysed using one-way analysis of variance (ANOVA) with post hoc Tukey's test. All statistics were conducted in SPSS version 19 (IBM, USA). Values of $\mathrm{P} \leq 0.05$ were considered significant.

\section{Results}

\section{Extract composition and binding}

Catechine composition of the GTE ( $>95 \%$ polyphenols) was analysed by HPLC using external standards for the main components EGCG, EGC (epigallocatechin), ECG (epicatechingallate) and EC (epicatechin). The main catechine of the GTE was EGCG $(88.5 \pm 0.14 \%)$. Only minor fractions of other catechines were present in the order $\mathrm{ECG}>\mathrm{EGC}>\mathrm{EC}$ (i.e., $5.3 \pm 0.03 \%, 3.7 \pm 0.09 \%$ and $2.4 \pm 0.08 \%$, respectively). WPI was also analysed by HPLC and consisted primarily of bLG AB $(75.7 \pm 1.4 \%)$, with alpha-Lactalbumin $(14.7 \pm 0.1 \%)$ and $<4 \%$ bovine serum albumin (Keppler et al. 2017).

The combination of GTE and WPI resulted in a non-covalent interaction, which was analysed by ultrafiltration (Figure 1). Of the catechines present, only those which contained an esterified gallic acid, such as EGCG and ECG, showed a significant interaction with WPI. Furthermore, non-covalent binding of catechines to 
WPI decreased with increasing GTE concentration (i.e., $43.7 \%$ of the initial EGCG concentration in $64 \mu \mathrm{g} / \mathrm{ml}$ GTE was found to interact with $800 \mu \mathrm{g} / \mathrm{ml}$ WPI, whereas only $30.5 \%$ EGCG reacted after addition of 512 $\mu \mathrm{g} / \mathrm{ml}$ GTE). ECG bound in a similar way to WPI, although with a slightly lower binding capacity (i.e., $45.3 \%$ of the initial ECG concentration bound with WPI after addition of $64 \mu \mathrm{g} / \mathrm{ml} \mathrm{GTE}$, and $20.07 \%$ after addition of $512 \mu \mathrm{g} / \mathrm{ml} \mathrm{GTE}$ ). The loss of catechines due to unspecific membrane interactions and co-precipitation in the GTE during the ultrafiltration method was acceptable $(<22 \%)$.

\section{Antioxidant and antibacterial effects of GTE and WPI}

In the DPPH test (Figure 2), the antioxidative capacity of WPI and GTE were tested by their capacity to scavenge the free DPPH radical. GTE alone exhibited a scavenging capacity of 20 and $28 \%$ for 64 and 128 $\mu \mathrm{g} / \mathrm{ml}$ GTE, respectively. However, the addition of WPI had a significant negative effect on the radical scavenging capacity of GTE. For example, inclusion of $800 \mu \mathrm{g} / \mathrm{ml}$ WPI reduced inhibition to $\sim 13$ and $\sim 24 \%$ for 64 and $128 \mu \mathrm{g} / \mathrm{ml}$ GTE, respectively. There was no radical scavenging effect of WPI alone.

For antibacterial activity, results of MIC (Table 1) determination revealed that in the absence of WPI the GTE concentrations required to inhibit growth of the bacteria ranged between 128-256 $\mu \mathrm{g} / \mathrm{ml}$. GTE hindered growth of gram-positive bacteria more strongly than growth of the gram-negative P. aeruginosa. Addition of WPI decreased the MIC of GTE towards the gram-positive bacteria S. aureus ATCC 700699 and S. epidermidis ET086, and in particular $P$. acnes LMG 16711. In contrast, WPI increased the MIC towards the gram-negative P. aeruginosa ATCC 9027 .The growth of the yeast $C$. albicans ATCC MYA-2876 was not affected by GTE (MIC $>1024 \mu \mathrm{g} / \mathrm{ml}$, regardless of the addition of WPI).

\section{Proliferation of fibroblasts and hFOBs}

Fibroblasts cultured in the absence of GTE (Figure 3) showed a spindle-like morphology typical of healthy fibroblasts, as did those exposed to all concentrations of WPI $(0,50$ and $800 \mu \mathrm{g} / \mathrm{ml})$. However, increasing concentration of GTE appeared to promote the formation of round, apoptotic bodies, indicating the cells were preparing themselves for phagocytosis and were thus not viable. At a GTE concentration of $64 \mu \mathrm{g} / \mathrm{ml}$, only a few apoptotic bodies were observed. At $128 \mu \mathrm{g} / \mathrm{ml}$ GTE larger numbers of dead cells were detected, whilst at $256 \mu \mathrm{g} / \mathrm{ml}$ the majority of cells were dead. Higher GTE concentrations (data not shown) resulted in similar results as for $256 \mu \mathrm{g} / \mathrm{ml}$ GTE. Increasing WPI concentration to 50 or $800 \mu \mathrm{g} / \mathrm{ml}$ did not lead to an appreciable reduction in cell death. Hence, GTE concentrations above $128 \mu \mathrm{g} / \mathrm{ml}$ were excluded from further experiments.

For day $1 \mathrm{hFOB}$ cultures, 64 and $128 \mu \mathrm{g} / \mathrm{ml}$ GTE reduced cell proliferation (Figure 4). This effect was not changed by the addition of WPI. At day 4, 64 and $128 \mu \mathrm{g} / \mathrm{ml}$ GTE reduced cell proliferation, but this reduction was attenuated by inclusion of $800 \mu \mathrm{g} / \mathrm{ml}$ WPI. At day 7 , reduced cell proliferation was again observed with both 64 and $128 \mu \mathrm{g} / \mathrm{ml}$ GTE, though no attenuating effect of WPI was observed. At all GTE and WPI concentrations, the decrease in cell proliferation with GTE treatment was not a linear relationship.

WPI appears to promote small increases in cell proliferation, as in the absence of GTE $800 \mu \mathrm{g} / \mathrm{ml}$ WPI promoted cell proliferation at day 1 and 7. Furthermore, at $64 \mu \mathrm{g} / \mathrm{ml}$ GTE, proliferation was promoted by 800 $\mu \mathrm{g} / \mathrm{ml}$ WPI at day 1 and 4; whilst in the presence of $128 \mu \mathrm{g} / \mathrm{ml} \mathrm{GTE}, 800 \mu \mathrm{g} / \mathrm{ml}$ WPI promoted proliferation at day 4 only. $50 \mu \mathrm{g} / \mathrm{ml}$ WPI had no significant effect at any time point or GTE concentration. 
Images of hFOBs stained using the crystal violet method (Figure 5) agree with those for fibroblasts (Figure 3), and support crystal violet assay results (Figure 4). For example, hFOBs cultured in the absence of GTE formed healthy monolayers, though at a GTE concentration of $64 \mu \mathrm{g} / \mathrm{ml}$ markedly fewer cells were observed. Of these, some - but not all cells - displayed an elongated morphology, typical of good adhesion. However, at the highest GTE concentration of $128 \mu \mathrm{g} / \mathrm{ml}$ even fewer cells were observed, providing further evidence of the inhibitory effect of GTE on cell proliferation.

\section{Differentiation of hFOB cells}

Only 0 and $64 \mu \mathrm{g} / \mathrm{ml}$ concentrations of GTE were used in differentiation experiments, as $128 \mu \mathrm{g} / \mathrm{ml} \mathrm{GTE}$ had a detrimental effect on hFOB proliferation. Day 7 (Figure 6a) timepoint treatments showed the highest overall levels of alkaline phosphatase (ALP) activity. In WPI subgroup, $64 \mu \mathrm{g} / \mathrm{ml} \mathrm{GTE} \mathrm{treatments} \mathrm{showed} \mathrm{significantly}$ reduced ALP levels compared to those with no GTE. This trend is maintained at all timepoints, with the exception of the $0 \mu \mathrm{g} / \mathrm{ml}$ WPI subgroup at day 21, where ALP activity is very similar for both GTE treatments. WPI however shows a bell-shaped response, with $50 \mu \mathrm{g} / \mathrm{ml}$ concentrations causing increased ALP activity levels, compared to 0 and $800 \mu \mathrm{g} / \mathrm{ml}$ treatment wells. These increases for the $50 \mu \mathrm{g} / \mathrm{ml}$ treatment group are significant at day 7 , significant compared to the $800 \mu \mathrm{g} / \mathrm{ml}$ treatment at day 14 , and the $0 \mu \mathrm{g} / \mathrm{ml}$ treatments at day 21 .

\section{Discussion}

This study aimed to determine the combined effects of GTE and WPI, focusing on traits that would be useful for bone regeneration materials - such as antimicrobial and antioxidant activity, as well as impacts on osteoblast growth/differentiation. Firstly, binding assay results showed that significant complexes between GTE and WPI occurred. This was expected, given that previous studies have reported the binding efficiency of whey proteins with green tea catechines (Keppler et al. 2015). For example, galloylated cateines, such as EGCG and ECG, were found to react most strongly with proteins, and exhibited good antioxidative capacity (Bohin et al. 2012). Due to the nature of the non-covalent reaction, the catechins bound to the protein are always in equilibrium with unbound catechines, explaining the reported $50 \%$ binding of this work.

GTE's high radical inhibition capacity was also expected, being mediated by its $>95 \%$ polyphenol content, of which most take the form of EGCG (Supplementary Figure 1). Previous studies have shown EGCG and ECG to be two of the most potent radical scavenging flavonoids present in GTE (Salah et al. 1995; Hirano et al. 2001). However, the addition of WPI caused a masking effect on GTE scavenging activity, as evidenced by a decrease in its percentage inhibition. Such an effect on protein-bound polyphenols is probably mediated by hydrogen bonds, which occur between the hydroxyl groups of the catechines and the protein (Kanakis et al. 2011). A similar masking effect was observed for caseines with green tea catechines using the Trolox equivalent antioxidant capacity (TEAC) test (Arts et al. 2001), and forbLG and EGCG complexes using the ferric reducing ability of plasma (FRAP) test (Zorilla et al. 2011). Interestingly, this masking effect on percentage inhibition observed in the present study amounted to a reduction of approximately 4 to $7 \%$, after the addition of 50 and $800 \mu \mathrm{g} / \mathrm{ml}$ WPI, respectively. However, the binding assay showed an interaction of approximately $50 \%$ of the GTE. Therefore, it is likely that binding occurs in a way that leaves antioxidative groups of GTE partially available, even after interaction with the protein. 
The main drawback of the DPPH test is the low solubility of DPPH in water, thereby introducing ethanol into the system, which could denature the WPI. It was reported that denatured whey proteins interact more readily with GTE catechines (Keppler et al. 2014), which could result in an overestimation of the masking effect for native WPI. It should be kept in mind that antioxidant assays used here (and in the literature) are optimized to stabilize the radical in solution, which requires either solvents like ethanol or methanol, or the addition of different salts. This will always influence the analysis of antioxidative capacity for proteinpolyphenol complexes, because of the sensitivity of non-covalent binding reactions, which are likely altered even by the addition of salts or minor $\mathrm{pH}$ value changes.

GTE's anticipated antibacterial activity was confirmed in this study, with its inclusion at concentrations between $128-256 \mu \mathrm{g} / \mathrm{ml}$ inhibiting the growth of all bacteria tested. This is in agreement with similar work within the field, whereby GTE extracts of various forms were shown to have diverse antibacterial activity - such as against S. aureus, S. epidermidis, $P$. acnes and P. aeruginosa „Lee et al. 2009a; Sharma et al. 2012; Radji et al. 2013). In the present study, addition of WPI facilitated GTE's antibacterial activity toward P. acnes LMG 16711, with the MIC decreasing from 128 to $32 \mu \mathrm{g} / \mathrm{ml}(50 \mu \mathrm{g} / \mathrm{ml} \mathrm{WPI})$ and even $16 \mu \mathrm{g} / \mathrm{ml}(800 \mu \mathrm{g} / \mathrm{ml} \mathrm{WPI})$. A similar trend was also seen for S. aureus ATCC 700699 and S. epidermidis ET086, though MIC reduction was much less pronounced and was likely within the tests margin of error. For the Gram-negative Bacterium $P$. aeruginosa the opposite effect was seen, whereby addition of WPI gave rise to a drastic increase in MIC (from 256 to $1024 \mu \mathrm{g} / \mathrm{ml}$ ). Although the reasons behind the differences observed between Gram-positive and Gramnegative bacteria are unclear, the presence of a second (outer) membrane in Gram-negative bacteria may play an important role. It can be speculated that protein-bound catechins are less able to interact with peptidoglycan in the bacterial cell wall, making it difficult for these complexes to cross the outer membrane. EGCG also has a negative charge, which might be a reason for its lower affinity to Gram-negative bacteria (Yoda et al. 2004). Furthermore, it should be noted that previous work showed $P$. aeruginosa to have a MIC twice that of S. aureus (800 compared to $400 \mu \mathrm{g} / \mathrm{ml}$ ) (Radji et al. 2013), which may partly explain the increase in MIC seen after WPI inclusion. Finally, the fungus, C. albicans, did not respond at all to GTE treatment (MIC >1024 $\mu \mathrm{g} / \mathrm{ml}$ ). Previously, it was reported (Hirasawa and Takada 2004) that EGCG had an anti-C.albicans effect, which increased with increasing $\mathrm{pH}$ and concentration. In our study, $\mathrm{pH}$ was 7.4 and the concentration was 1000x lower, which may explain the lack of response seen. However, the mechanism of GTE's anti-C. albicans effect remains unclear.

Good antibacterial and antioxidant capacity are both desirable characteristics for regeneration materials, helping support a heathy healing site after bone damage. However, cell response also needs to be determined, to ensure cytocompatibility before clinical application. Fibroblast images (figure 3 ) helped to give a qualitative insight into GTE and WPI's effect, showing WPI to have no obvious impact on cell adhesion or morphology. However, increasing GTE concentration caused significant changes in cell morphology, attachment and increased mortality. This is similar to findings of another study, whereby both normal and keloid fibroblasts were shown to decrease proliferation in a dose-dependent manner with EGCG treatment (Park et al. 2008). Returning to the present study, fibroblast findings were also mirrored in proliferation results of an osteoblast-like cell line (hFOB 1.19), whereby $800 \mu \mathrm{g} / \mathrm{ml}$ WPI increased cell growth. Alternatively, GTE inclusion reduced proliferation, particularly at later time intervals, and this was only partially mitigated by the addition of WPI. 
Previous work reports that WPI, especially its component bLG, has a mitotic effect on different cell types, which would explain its stimulative effect on hFOB proliferation. For instance, Gillespie et al. reported that bLG (312.5-2500 $\mu \mathrm{g} / \mathrm{ml})$ improved the proliferation of enteroendocrine cells (Gillespie et al. 2015), whilst another study investigated mouse spleen resting cells. Here, a proliferative effect was found in the concentration range 50-500 $\mu \mathrm{g} / \mathrm{ml}$, over 12-96 hours (Mahmud et al. 2004). For GTE polyphenols, the literature often reports a positive effect on bone metabolism, such as increased osteoblast maturation and production of mineralised material (Ko et al. 2009). Our opposite finding could be due to the different composition of catechins used in this study, as work by Ko et al. (Ko et al. 2009) did not include EGCG specifically. Alternatively, it may indicate that even the minimum GTE concentration used in this work was too high, causing suppressive effects on cell activity. In support of this, other similar studies using osteoblast-like cells tended to use lower concentrations, compared to the 64 and $128 \mu \mathrm{g} / \mathrm{ml}$ doses of the present study. For example, rat mesenchymal stem cells (Ko et al. 2011), Saos-2 (Nash and Ward 2016) and human osteoblast cells (Vester et al. 2014) all showed increased levels of cell differentiation and limited cytotoxicity when treated with GTE concentrations of around $10 \mu \mathrm{g} / \mathrm{ml}$ (a maximum of 50 and minimum of $0.01 \mu \mathrm{g} / \mathrm{ml}$ ). Another similar study, testing EGCG, demonstrated no toxic effect at $10 \mu \mathrm{g} / \mathrm{ml}$ (Lee et al. 2009b); and whilst higher concentrations are occasionally tested, exposure times are generally shorter. For example, rat calvarial osteoblasts were treated with green tea polyphenols at a $200 \mathrm{\mu g} / \mathrm{ml}$ dose, to prevent alterations upon exposure to $\mathrm{H}_{2} \underline{\mathrm{O}}_{2}$; though only for a 1 hour period (Park et al. 2003). Returning to the present study, GTE's inclusion also reduced bLG bioactivity, or bioavailability, which most likely resulted from binding between the two extracts.

The final indicator of cell activity investigated was ALP, expressed during osteoblast maturation, which is considered an early marker of osteogenic differentiation (Setzer et al. 2009). Though it was evaluated on days 7, 14 and 21, the highest ALP activity was measured on day 7, in the $50 \mu \mathrm{g} / \mathrm{ml}$ WPI treatment group. The consistently high ALP activity in this treatment, compared to 0 and $800 \mu \mathrm{g} / \mathrm{ml}$, indicates WPI has an optimal concentration able to stimulate hFOB differentiation. On the other hand, GTE caused a decrease in ALP activity, often reducing the activity levels by $50 \%$ or more in wells with no GTE added. This is in agreement with a study (Yamaguchi and Ma 2001) concerning the effect of polyphenols on ALP activity in rat femoral tissues, which concluded that EGCG $(0.1 \mathrm{mM})$ significantly inhibited ALP activity. Furthermore, the current study's results appear to support a previously reported interaction between ALP and polyphenols from the seaweed-derived nutritional supplement Seanol® (Douglas et al. 2016). Here, a similar concentration of polyphenols were used in supplements, which were shown to have reduced release rates during ALP-mediated mineralisation. However, it is important to note there are also several studies where treatment with GTE increased osteoblast differentiation, such as with the aforementioned work using rat mesenchymal stem cells (Ko et al. 2011), Saos-2 (Nash and Ward 2016), and human osteoblast cells (Vester et al. 2014). These cells showed increased levels of many differentiation indicators, including ALP activity, mineralisation levels and gene expression for proteins including sclerostin, osteopontin and osteocalcin. The contrasting reports of GTE both inhibiting and promoting cell differentiation are likely a reflection of the overall concentration and polyphenol content of each extract tested. Finally, in terms of the present study's interaction effects of GTE and WPI, GTE again reduced WPI bioactivity. However, the presence of 50 or $800 \mu \mathrm{g} / \mathrm{ml}$ WPI did not obviously mitigate the negative effect of $64 \mu \mathrm{g} / \mathrm{ml}$ GTE, indicating more WPI binding is needed to promote hFOB differentiation in these treatments. 
Cell based assay results are arguably the most important when determining a compound or extract's suitability for different applications, such as tissue engineering. GTE's cytotoxicity, whilst slightly mitigated by WPI, makes it unsuitable for inclusion at sites undergoing skeletal regeneration, as it would likely limit osteoblast activity. One related limitation of this work was the minimum GTE concentration tested, of $64 \mu \mathrm{g} / \mathrm{m} 1$. Lower concentrations may have preserved GTE's antimicrobial and antioxidant capacity, whilst also limiting cytotoxicity - especially with WPI inclusion. Similarly, further processing of GTE could have been conducted, to create GTE treatments with different polyphenol compositions and potentially better cytocompatibility.

This work demonstrated the affinity of WPI for components of GTE, and the formation of WPI/GTE complexes. GTE displayed excellent antioxidative capacity, which was not significantly affected by addition of WPI; though some masking effect is possible. Furthermore, GTE showed antimicrobial activity against grampositive and gram-negative bacteria, with WPI inclusion potentiating this effect on several types of grampositive bacteria. However, with cells GTE showed cytotoxic and suppressive effects on both fibroblasts and hFOBs, especially at concentrations of $128 \mu \mathrm{g} / \mathrm{ml}$ and above. WPI alone though enhanced hFOB proliferation and attenuated the suppressive effect of GTE at $64 \mu \mathrm{g} / \mathrm{ml}$, to a certain extent. For hFOB differentiation, WPI significantly stimulated ALP activity at a $50 \mu \mathrm{g} / \mathrm{ml}$ concentration, though was less able to attenuate effects of GTE inclusion. These results therefore show that WPI and GTE both have useful properties, but the cytotoxicity of GTE makes it unsuitable for inclusion within a tissue engineered construct.

\section{Acknowledgement and ethical approval, informed consent and conflict of interest statements}

FWO, Belgium for a postdoctoral fellowship (T.E.L.D.). BOF of Ghent University for financial support (A.G.S.). DFG, Germany for funding (J.K.K.). N. Mathijs, M. Paymard-Stolz and M. Pfeiler for excellent technical assistance. Ethical approval was obtained from the relevant ethics committee. Informed consent was obtained from patients. The authors have no conflict of interest.

\section{References}

Arts M.J.T.J., Haenen G.R.M.M., Voss H.P. \& Bast A. (2001) Masking of antioxidant capacity by the interaction of flavonoids with protein. Food and Chemical Toxicology 39:787-791.

Bai X.C., Lu D., Liu A.L., Zhang Z.M., Li X.M., Zou Z.P., Zeng W.S., Cheng B.L. \& Luo S.Q. (2005) Reactive oxygen species stimulates receptor activator of NF-kappa B ligand expression in osteoblast. Journal of Biological Chemistry 280:17497-17506.

Bohin M.C., Vincken J.P., van der Hijden H.T.W.M. \& Gruppen H. (2012) Efficacy of Food Proteins as Carriers for Flavonoids. Journal of Agricultural and Food Chemistry 60:4136-4143.

Chen T., Yu W.H., Izard J., Baranova O.V., Lakshmanan A. \& Dewhirst F.E. (2010) The Human Oral Microbiome Database: a web accessible resource for investigating oral microbe taxonomic and genomic information. Database-the Journal of Biological Databases and Curation

Clawin-Radecker I., Kiesner C. \& Schlimme E. (2000) Analysis of the acid-soluble contents of alphalactalbumin, beta-lactoglobulin, serum albumin and of the immunoglobulin fraction in pasteurized milk. Kieler Milchwirtschaftliche Forschungsberichte 52:323-334. 
Douglas T.E., Dokupil A., Reczynska K., Brackman G., Krok-Borkowicz M., Keppler J.K., Bozic M., Van Der Voort P., Pietryga K., Samal S.K., Balcaen L., van den Bulcke J., Van Acker J., Vanhaecke F., Schwarz K., Coenye T. \& Pamula E. (2016) Enrichment of enzymatically mineralized gellan gum hydrogels with phlorotannin-rich Ecklonia cava extract Seanol((R)) to endow antibacterial properties and promote mineralization. Biomed Mater 11:045015.

Garrett I.R., Boyce B.F., Oreffo R.O.C., Bonewald L., Poser J. \& Mundy G.R. (1990) Oxygen-Derived FreeRadicals Stimulate Osteoclastic Bone-Resorption in Rodent Bone In vitro and In vivo. Journal of Clinical Investigation 85:632-639.

George K., Zafiropoulos G.G.K., Murat Y., Hubertus S. \& Nisengard R.J. (1994) Clinical and Microbiological Status of Osseointegrated Implants. Journal of Periodontology 65:766-770.

Gharib A., Faezizadeh Z. \& Godarzee M. (2013) Therapeutic efficacy of epigallocatechin gallate-loaded nanoliposomes against burn wound infection by methicillin-resistant Staphylococcus aureus. Skin Pharmacol Physiol 26:68-75.

Gillespie A.L., Calderwood D., Hobson L. \& Green B.D. (2015) Whey proteins have beneficial effects on intestinal enteroendocrine cells stimulating cell growth and increasing the production and secretion of incretin hormones. Food Chem 189:120-128.

Gosau M., Haupt M., Thude S., Strowitzki M., Schminke B. \& Buergers R. (2016) Antimicrobial effect and biocompatibility of novel metallic nanocrystalline implant coatings. J Biomed Mater Res B Appl Biomater 104:1571-1579.

Harbaum B., Hubbermann E.M., Zhu Z. \& Schwarz K. (2008) Impact of fermentation on phenolic compounds in leaves of pak choi (Brassica campestris L. ssp. chinensis var. communis) and Chinese leaf mustard (Brassica juncea coss). J Agric Food Chem 56:148-157.

Hirano R., Sasamoto W., Matsumoto A., Itakura H., Igarashi O. \& Kondo K. (2001) Antioxidant ability of various flavonoids against DPPH radicals and LDL oxidation. Journal of Nutritional Science and Vitaminology 47:357-362.

Hirasawa M. \& Takada K. (2004) Multiple effects of green tea catechin on the antifungal activity of antimycotics against Candida albicans. Journal of Antimicrobial Chemotherapy 53:225-229.

Jin P., Wu H., Xu G., Zheng L. \& Zhao J. (2014) Epigallocatechin-3-gallate (EGCG) as a pro-osteogenic agent to enhance osteogenic differentiation of mesenchymal stem cells from human bone marrow: an in vitro study. Cell Tissue Res 356:381-390.

Kanakis C.D., Hasni I., Bourassa P., Tarantilis P.A., Polissiou M.G. \& Tajmir-Riahi H.A. (2011) Milk beta$\underline{\text { lactoglobulin complexes with tea polyphenols. Food Chemistry 127:1046-1055. }}$

Kavanagh K.T., Abusalem S. \& Calderon L.E. (2017) The incidence of MRSA infections in the United States: is a more comprehensive tracking system needed? Antimicrob Resist Infect Control 6:34.

Keppler J.K., Martin D., Garamus V.M., Berton-Carabin C., Nipoti E., Coenye T. \& Schwarz K. (2017) Functionality of whey proteins covalently modified by allyl isothiocyanate. Part 1 physicochemical and antibacterial properties of native and modified whey proteins at $\mathrm{pH} 2$ to 7 . Food Hydrocolloids 65:130$\underline{143 .}$ 
Keppler J.K., Martin D., Garamus V.M. \& Schwarz K. (2015) Differences in binding behavior of (-)epigallocatechin gallate to -lactoglobulin heterodimers ( $\mathrm{AB}$ ) compared to homodimers (A) and (B). Journal of Molecular Recognition 28:656-666.

Keppler J.K., Sonnichsen F.D., Lorenzen P.C. \& Schwarz K. (2014) Differences in heat stability and ligand binding among beta-lactoglobulin genetic variants $\mathrm{A}, \mathrm{B}$ and $\mathrm{C}$ using $\mathrm{H}-1$ NMR and fluorescence quenching. Biochimica Et Biophysica Acta-Proteins and Proteomics 1844:1083-1093.

Klein S., Nurjadi D., Eigenbrod T. \& Bode K.A. (2016) Evaluation of antibiotic resistance to orally administrable antibiotics in staphylococcal bone and joint infections in one of the largest university hospitals in Germany: is there a role for fusidic acid? Int J Antimicrob Agents 47:155-157.

Ko C.H., Lau K.M., Choy W.Y. \& Leung P.C. (2009) Effects of tea catechins, epigallocatechin, gallocatechin, and gallocatechin gallate, on bone metabolism. J Agric Food Chem 57:7293-7297.

Ko C.H., Siu W.S., Wong H.L., Shum W.T., Fung K.P., Lau C.B.S. \& Leung P.C. (2011) Pro-bone and Antifat Effects of Green Tea and Its Polyphenol, Epigallocatechin, in Rat Mesenchymal Stem Cells in Vitro. Journal of Agricultural and Food Chemistry 59:9870-9876.

Kontopidis G., Holt C. \& Sawyer L. (2004) Invited review: beta-lactoglobulin: binding properties, structure, and function. J Dairy Sci 87:785-796.

Lee J.H., Shim J.S., Chung M.S., Lim S.T. \& Kim K.H. (2009a) In vitro anti-adhesive activity of green tea extract against pathogen adhesion. Phytother Res 23:460-466.

Lee Y.L., Hong C.Y., Kok S.H., Hou K.L., Lin Y.T., Chen M.H., Wang C.C. \& Lin S.K. (2009b) An Extract of Green Tea, Epigallocatechin-3-Gallate, Reduces Periapical Lesions by Inhibiting Cysteine-rich 61 Expression in Osteoblasts. Journal of Endodontics 35:206-211.

Mahmud R., Matin M.A. \& Otani H. (2004) Mitogenic effect of bovine beta-lactoglobulin and its proteolytic digests on mouse spleen resting cells. Pakistan Journal of Biological Sciences 7:2045-2050.

Mann B., Kumari A., Kumar R., Sharma R., Prajapati K., Mahboob S. \& Athira S. (2015) Antioxidant activity of whey protein hydrolysates in milk beverage system. Journal of Food Science and TechnologyMysore 52:3235-3241.

Moulti-Mati F., Mati A., Capiaumont J., Belleville F., Linden G. \& Nabet P. (1991) Rôle de la betalactoglobuline dans l'activité proliférative du lactosérum. Lait 71:543-553.

Nash L.A. \& Ward W.E. (2016) Comparison of black, green and rooibos tea on osteoblast activity. Food \& Function 7:1166-1175.

Park G., Yoon B.S., Moon J.H., Kim B., Jun E.K., Oh S., Kim H., Song H.J., Noh J.Y., Oh C. \& You S. (2008) Green tea polyphenol epigallocatechin-3-gallate suppresses collagen production and proliferation in keloid fibroblasts via inhibition of the STAT3-signaling pathway. Journal of Investigative Dermatology 128:2429-2441.

Park Y.H., Han D.W., Suh H., Ryu G.H., Hyon S.H., Cho B.K. \& Park J.C. (2003) Protective effects of green tea polyphenol against reactive oxygen species-induced oxidative stress in cultured rat calvarial osteoblast. Cell Biology and Toxicology 19:325-337.

Radji M., Agustama R.A., Elya B. \& Tjampakasari C.R. (2013) Antimicrobial activity of green tea extract against isolates of methicillin-resistant Staphylococcus aureus and multi-drug resistant Pseudomonas aeruginosa. Asian Pac J Trop Biomed 3:663-667; discussion 666. 
Salah N., Miller N.J., Paganga G., Tijburg L., Bolwell G.P. \& Riceevans C. (1995) Polyphenolic Flavanols as Scavengers of Aqueous-Phase Radicals and as Chain-Breaking Antioxidants. Archives of Biochemistry and Biophysics 322:339-346.

Serfert Y., Lamprecht C., Tan C.P., Keppler J.K., Appel E., Rossier-Miranda F.J., Schroen K., Boom R.M., Gorb S., Selhuber-Unkel C., Drusch S. \& Schwarz K. (2014) Characterisation and use of betalactoglobulin fibrils for microencapsulation of lipophilic ingredients and oxidative stability thereof. Journal of Food Engineering 143:53-61.

Setzer B., Bachle M., Metzger M.C. \& Kohal R.J. (2009) The gene-expression and phenotypic response of hFOB 1.19 osteoblasts to surface-modified titanium and zirconia. Biomaterials 30:979-990,

Sharma A., Gupta S., Sarethy I.P., Dang S. \& Gabrani R. (2012) Green tea extract: possible mechanism and antibacterial activity on skin pathogens. Food Chem 135:672-675.

Steinmann J., Buer J., Pietschmann T. \& Steinmann E. (2013) Anti-infective properties of epigallocatechin-3gallate (EGCG), a component of green tea. Br J Pharmacol 168:1059-1073.

Tobi S.E., Gilbert M., Paul N. \& McMillan T.J. (2002) The green tea polyphenol, epigallocatechin-3-gallate, protects against the oxidative cellular and genotoxic damage of UVA radiation. International Journal of Cancer 102:439-444.

Tong L.M., Sasaki S., McClements D.J. \& Decker E.A. (2000) Mechanisms of the antioxidant activity of a high molecular weight fraction of whey. Journal of Agricultural and Food Chemistry 48:1473-1478.

Vali B., Rao L.G. \& El-Sohemy A. (2007) Epigallocatechin-3-gallate increases the formation of mineralized bone nodules by human osteoblast-like cells. J Nutr Biochem 18:341-347.

Vester H., Holzer N., Neumaier M., Lilianna S., Nussler A.K. \& Seeliger C. (2014) Green Tea Extract (GTE) improves differentiation in human osteoblasts during oxidative stress. Journal of Inflammation-London $\underline{11}$

Wauquier F., Leotoing L., Coxam V., Guicheux J. \& Wittrant Y. (2009) Oxidative stress in bone remodelling and disease. Trends in Molecular Medicine 15:468-477.

Yamaguchi M. \& Ma Z.J. (2001) Effect of polyphenols on calcium content and alkaline phosphatase activity in rat femoral tissues in vitro. Biological \& Pharmaceutical Bulletin 24:1437-1439.

Yoda Y., Hu Z.Q., Zhao W.H. \& Shimamura T. (2004) Different susceptibilities of Staphylococcus and Gramnegative rods to epigallocatechin gallate. J Infect Chemother 10:55-58.

Zhao W.H., Hu Z.Q., Okubo S., Hara Y. \& Shimamura T. (2001) Mechanism of synergy between epigallocatechin gallate and beta-lactams against methicillin-resistant Staphylococcus aureus. Antimicrob Agents Chemother 45:1737-1742.

Zorilla R., Liang L., Remondetto G. \& Subirade M. (2011) Interaction of epigallocatechin-3-gallate with betalactoglobulin: molecular characterization and biological implication. Dairy Science \& Technology 91:629-644.

\section{Figure captions}


Figure 1: GTE compounds that were bound to $800 \mu \mathrm{g} / \mathrm{ml} \mathrm{WPI}$, as a function of the GTE $[\mu \mathrm{g} / \mathrm{ml}]$ concentration. Abbreviations: EGC, Epigallocatechin; EC, epicatechin; EGCG, epigallocatechin gallate, ECG, epicatechingallate; GTE, green tea extract

Figure 2: Antioxidative capacity (DPPH test) of different concentrations of GTE, with or without addition of 800 or $50 \mu \mathrm{g} / \mathrm{ml}$ WPI. All values are listed as mean \pm standard deviation $(\mathrm{n}=3) . *$ : $\mathrm{p}<0.05$

Figure 3: Images of fibroblasts cultured in cell culture medium containing different concentrations of GTE (epigallocatechin gallate-rich extract) and WPI (beta-lactoglobulin-rich extract) after $7 \mathrm{~d}$. Scale bar $=100 \mu \mathrm{m}$ in all cases.

Figure 4: Data from day 1 (a), 4 (b) and 7 (c) crystal violet assay conducted on hFOB cells. Results are presented as the mean optical density values for each treatment, $(n=4,+/-\mathrm{SD})$. * indicates a significant difference $(\mathrm{p}<0.05)$ between the treatment and the $0 \mu \mathrm{g} / \mathrm{ml}$ GTE value (within each WPI treatment group). \# indicates a significant difference $(\mathrm{p}<0.05)$ between the treatment and the respective value for WPI $=0 \mu \mathrm{g} / \mathrm{ml}$.

Figure 5: Images taken of hFOBs using an ISH500 camera attached to an OLYMPUS SZX10 microscope at 2x zoom. $\mathrm{hFOB}$ cells were fixed and stained with crystal violet 7 days after initial treatment. Scale bar $=1 \mathrm{~mm}$ in all cases.

Figure 6: data from an ALP assay conducted on hFOBs. Cells were given a 24 hour attachment period before being treated with solutions containing different concentrations of GTE and WPI. The assay was conducted on day 7 (a), day 14 (b) and day 21 (c) timepoints. Each ALP reading was normalized to the DNA concentration of the same well, calculated via PicoGreen assay. Results are presented as the mean $+/-$ standard deviation $(n=4)$. *p $<0.05$ for WPI treatments at $64 \mu \mathrm{g} / \mathrm{ml}$ GTE, compared to WPI treatments of the same concentration at $0 \mathrm{ug} / \mathrm{ml}$ GTE. \#p $<0.05$ for WPI treatment comparisons at $0 \mu \mathrm{g} / \mathrm{ml}$ GTE. 